\title{
Mercury contamination in the Red river watershed: a review of the contaminated sites
}

\author{
Dang Thi $\mathrm{Ha}^{* 1}$, Alexandra Coynel$^{2}$, Marine Deschatre ${ }^{2}$ \\ ${ }^{1}$ Institute of Chemistry, VAST-Hanoi, Vietnam \\ ${ }^{2}$ University of Bordeaux 1, UMR CNRS 5805 EPOC, France
}

Accepted 27 December 2014

\section{ABSTRACT}

This study is based on two sampling campaigns covering the whole Vietnamese Red River watershed in 40 sites at low and high water levels during 2009 in order to determine the seasonal and spatial variations of $\mathrm{Hg}$ concentrations in stream sediments. The results showed that the $\mathrm{Hg}$ concentrations during low water level were clearly higher than that during high water level, demonstrating an effect of particle (grain) size (i.e. significant contribution of less mercury-contaminated particles in high water level). In addition, in order to assess spatial distribution of the $\mathrm{Hg}$ contamination in the Red River watershed and localize geochemical anomalies, multidimensional statistical analyses combined with $\mathrm{Hg}$ maps generated by GIS tool were used. We observed that the high mercury anomalies are originated from the important pollutant sources (mining/smelting) located in the upstream and mid- Red River watershed, demonstrating an impact of anthropogenic activities on river Hg concentrations. Finally, the comparison between the $\mathrm{Hg}$ concentrations in the stream sediment from the Red River watershed and the consensus-based freshwater sediment quality guidelines (SQGs) indicated that the sediment quality for important areas of the Red River watershed is rather poor and probably represents serious threats to aquatic life.

Keywords: Red River, Hg contamination,anomaly,sediment quality,GIS.

(C) 2014 Vietnam Academy of Science and Technology

\section{Introduction}

Mercury is known as one of the environmental pollutants, enhancing its toxicity for aquatic organisms and bioaccumulation in the food chain (Balogh et al., 1998; Brigham et al., 2009; Maria et al., 1997). Hg contaminated sites persist and many studies have been performed to determine contamination levels, assessment of risks, behavior and fate of this element and its compounds in the different environmental compartments. The both natural (rock weathering, erosion) and anthropogenic sources contribute in variable proportions to mercury concentration in river

"Corresponding author, Email: leha1645@yahoo.com
(Baloghet al., 1998; Brigham et al, 2009; Guangle et al., 2006; Maria et al.,1997; Mlayahet et al., 2009). Stream sediment represents one of the ultimate sinks for metal discharged into the aquatic environment and is commonly used in environmental studies to evaluate concentrations of chemical elements in soils over wide areas and to identity possible sources of anomalies such as ore deposits (geochemical exploration) or anthropogenic sources (Guangle et al., 2006; Mlayah et al., 2009).

The Red River (Fig. 1), drainage in Himalaya, is the one of largest rivers in the South-East Asia and contributes significantly to the global sediment budget and water discharge to the ocean (Dang 
Dang Thi Ha et al./Vietnam Journal of Earth Sciences 36 (2014)

T.H. et al., 2010, 2011; Le T.P.Q. et al., 2007). Much research has been done on the contamination of heavy metal such as $\mathrm{As}, \mathrm{Cu}, \mathrm{Pb}$ and of nutrient salts in the Red River Delta in Vietnam, showing a serious health threat to millions of people living in this area (Berg et al., 2007; Dang T.H. et al., 2010; Ho. et al., 2010; Le T.P.Q. et al, 2007; Nguyen M.P. et al., 2010). However, metal contaminations in the upstream Red River watershed are generally poorly documented, especially merc.ury element.

In order to determine spatial - seasonal $\mathrm{Hg}$ concentration variations and localize $\mathrm{Hg}$ anomalies in the Red River watershed, this paper presents the first data of mercury concentrations measured in stream sediments from 40 points throughout the Red River watershed in Vietnamese part in two contrasting hydrological conditions during 2009: high and low water levels. In addition, mercury concentrations of the Red River were compared to the consensus-based freshwater sediment quality guidelines (SQGs) for estimation of potential toxic effects on aquatic environment.

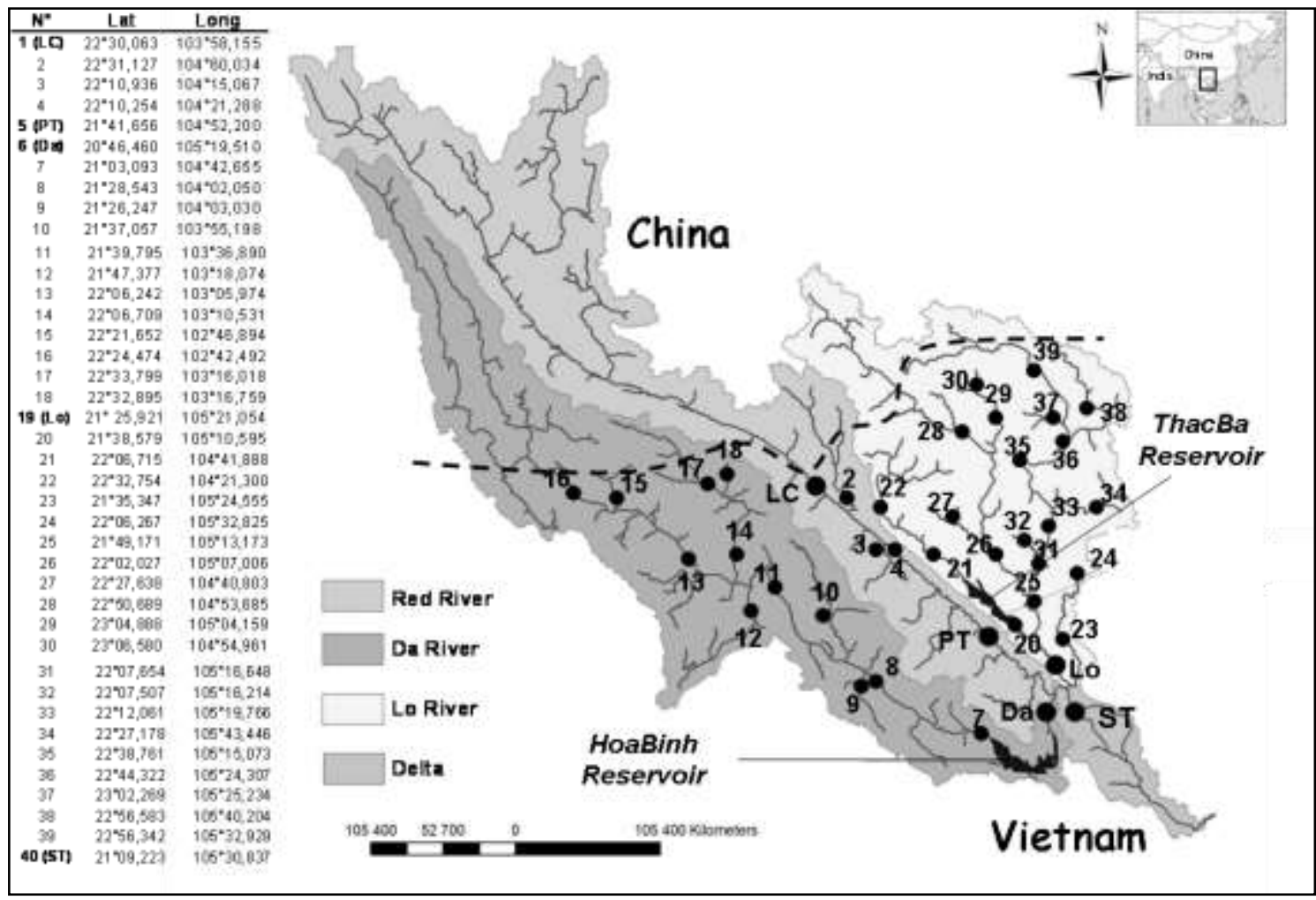

Figure 1. Description of the Red River watershed and sampling strategy: location of study sites during two spatial sampling campaigns (black points) and the sampling site coordinates. The black dashed line represents the China/Vietnam boundary

\section{Materials and methods}

\subsection{Area descriptions}

The Red River originates from the mountainous area of Yunnan Province in China, flows $1200 \mathrm{~km}$ south-eastward and then flows through seven Vietnamese provinces before flowing into the Gulf of Tonkin in the South China Sea, with the total watershed area of $169,000 \mathrm{~km}^{2}$ (50.3\% of which in Vietnam, $48.8 \%$ in China and $0.9 \%$ in Laos; Fig. 1). The red laterite soils are abundant in this mountainous area and give the river its characteristic color Schäfer et al.,2006). The main tributaries of the Red River are the Da River, on the right bank, and the Lo River, on the left bank. The Da River has its source in the Yunnan Province, near to that of the upstream Red River, at an elevation $>2000 \mathrm{~m}$ (Adrienne et al., 2008).

The Red River watershed is characterized by two distinct seasons: the wet season from May to 
October and the dry season from November to April, due to the South West monsoon in summer and the North East monsoon in winter, respectively. The summer season is warm and very humid, with mean temperatures ranging from $27^{\circ} \mathrm{C}$ to $29^{\circ} \mathrm{C}$ whereas the winter season is cool and dry with mean monthly temperatures ranging from $16^{\circ} \mathrm{C}$ to $21^{\circ} \mathrm{C}$ (Fig. 2). Average annual rainfall in the Red River System is $1600 \mathrm{~mm}$, with $85 \%-95 \%$ of this falling during the summer season.

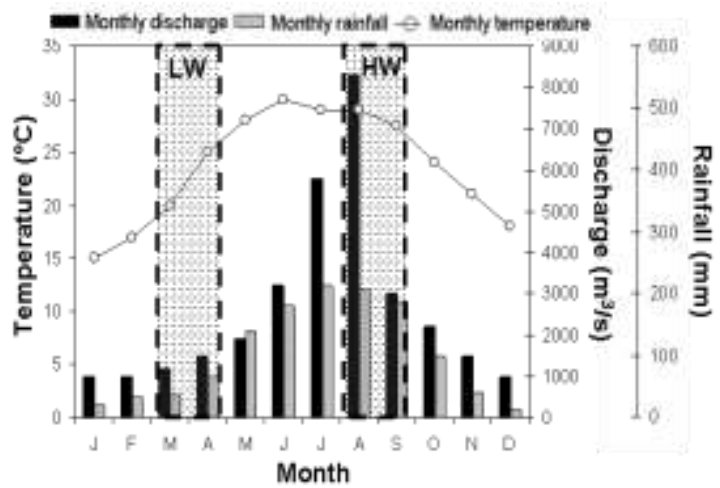

Figure 2. Description of monthly averages of temperature, water discharge and rainfall of the Red River (LW, HW: sampling spatial campaign at low water and high water levels)

\subsection{Data and methodology}

Sampling frequency: during 2009, sampling campaigns were performed at 40 points throughout the Vietnamese part of the Red River watershed in two contrasting hydrological conditions: low water discharge in Mars - April 2009 and medium to high water discharge in August - September 2009 (Fig. 1, 2). The coordinates of the sampling location were recorded with a differential GPS. At each site, the dissolved, stream sediment samples were measured (Fig. 1). The coordinates of the sampling are listed in Figure 1.

Sampling and sample treatment:stream sediment samples were manually collected using a plastic spatula, consisting of the uppermost $1 \mathrm{~cm}$ of sediment from several recent depositional pockets within a distance of twenty five meters. Stream sediment samples were sieved $(<63 \mu \mathrm{m}$; nylon sieves) to remove coarse material which was obviously not representative of typical grain size of suspended particulate matter. Thus, sediments were dried in an over at $50^{\circ} \mathrm{C}$ for 24 hours.
Mercury analyses: Sediment $\mathrm{Hg}$ concentration was analyzed from the dry, homogenized material by cold vapor atomic absorption spectrometry after calcination under an $\mathrm{O} 2$ stream and amalgamation on a $\mathrm{Au}$ trap using automated $\mathrm{Hg}$ analyzers (ALTEC-AMA-254 and MILESTONE-DMA-80). The results were expressed in $\mu \mathrm{g} / \mathrm{kg}$ (dry weight) and the detection limit (3 times the standard deviation of 5 blank values) varied daily from 1 to $2 \mu \mathrm{g} / \mathrm{kg}$. The accuracy of the analytical results was checked by analyzing certified reference materials (CRM 320, PACS-1, SL-1) after each set of 4 samples. Precision (coefficient of variation of 5 replicate samples) was better than $5 \%$ and results were consistently within the certified concentration intervals. These analyses were performed at the Laboratory of UMR 5805 EPOC (France).

\section{Results and discussion}

\subsection{Variability of total $\mathrm{Hg}$ concentrations in stream sediment}

The Figure 3A presents the statistical parameters (including the arithmetic average, median, 10- and 90-centiles, minimum and maximum) of $\mathrm{Hg}$ concentration in stream sediment from 40 sampling sites in the Vietnamese part of the Red River watershed measured during high and low water levels in 2009. The results showed that the mercury concentration in stream sediments is strong spatial and seasonal variations (Fig. 3A). In fact, in low water level, the $\mathrm{Hg}$ concentrations varied between 71 and $475 \mu \mathrm{g} / \mathrm{kg}$ in low water condition (i.e. $\mathrm{max} / \mathrm{min}$ ratio $\sim 6.7$ ) and its values varied between 66 and $241 \mu \mathrm{g} / \mathrm{kg}$ in high water condition (i.e. $\max / \mathrm{min}$ ratio $\sim 3.7$; Fig. $3 \mathrm{~A}$ ). The average $\mathrm{Hg}$ concentrations in stream sediment were $126 \mu \mathrm{g} / \mathrm{kg}$ and $195 \mu \mathrm{g} / \mathrm{kg}$ in high water and low water levels, respectively. We noted that the $\mathrm{Hg}$ concentrations in stream sediment of the Red River during high water level were clearly lower than that during low water level. This phenomenon has been observed in many rivers in the world and can explain by the important contribution of less $\mathrm{Hg}$-contaminated sediments (alluvial floor of the channel and bank deposits) and/or a higher percentage of relatively coarse material in rainy season (e.g. 5, 12). 
Dang Thi Ha et al./Vietnam Journal of Earth Sciences 36 (2014)

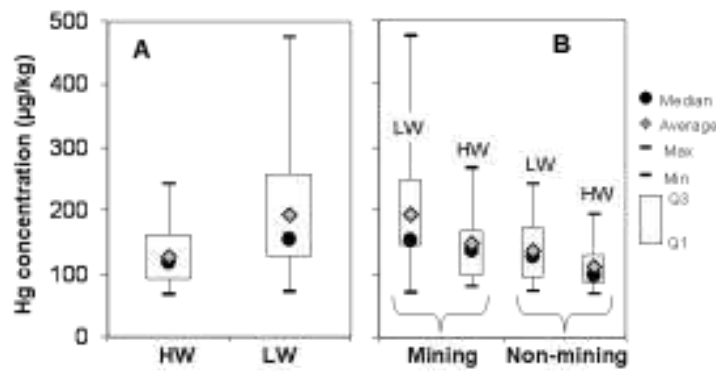

Figure 3. Box plots of $\mathrm{Hg}$ concentrations in stream sediment of the Red River in two specific campaigns during low and high waters (LW and HW) in 2009 (A), and Box plots of $\mathrm{Hg}$ concentrations (in $\mu \mathrm{g} / \mathrm{kg}$ ) in stream sediments of the Red River watershed in tailing and non-tailing groups in high water (HW) and low water (LW) conditions (B).

As a comparison, the $\mathrm{Hg}$ concentrations measured in the Red River were comparable to those observed in the other rivers like the Garonne River $(200 \mu \mathrm{g} / \mathrm{kg}$, (Schäfer et al., 2006) or the Lawrence River $(180 \mu \mathrm{g} / \mathrm{kg}$, (Adrienne et al., 2008). They are higher than those measured in the OuedMellègue, Tunisia $(40 \mu \mathrm{g} / \mathrm{kg}$, (Mlayah A et al., 2009) or the Resurrection Creek River, Alaska $(60 \mu \mathrm{g} / \mathrm{kg}$, (MacFarlane., 2004). As suspected, they are really lower than those of the Lot River $(880 \mu \mathrm{g} / \mathrm{kg}$, e.g. Coynel et al., 2009), the Yamuna (tributary of the Ganges River, $5000 \mu \mathrm{g} / \mathrm{kg}$, (Subramanian et al., 2003) or the Guyana River
$(2400 \mu \mathrm{g} / \mathrm{kg}$, afterSpadini et al., 2003). It's very interesting to note that the world average value of $\mathrm{Hg}$ concentration in stream sediment is $150 \mu \mathrm{g} / \mathrm{kg}$, established by Viers et al. 2009.

\subsection{Spatial distribution analysis assisted by GIS tool}

The $\mathrm{Hg}$ concentrations measured in stream sediment in the Red River watershed showed strong spatial variations. In order to clearly the spatial distribution and determine $\mathrm{Hg}$ sources of $\mathrm{Hg}$ concentrations in Vietnamese part of the Red River watershed, $\mathrm{Hg}$ concentrations obtained from 40 sites in the Vietnamese part were used to establish the maps assisted by GIS tool. Geographic Information System (GIS; Mapinfo version 7.5) was used to treat Topographical, geological data and metal/metalloid concentrations. According to the coordinates of the sampling locations of 40 sites in the hydrological network during two specific campaigns, the limits and areas of the respective drainage basins have been extracted. Mercury concentrations were considered as generally representative of the watershed area upstream from the sampling point.

For purposes of comparison with the world average concentration of $150 \mu \mathrm{g} / \mathrm{kg}$, the measured concentrations ranges were separated into 4 classes, each class represents concentration ranges $<150,150-250,250-350$ and $>350 \mu \mathrm{g} / \mathrm{kg}$ (Fig. 4).

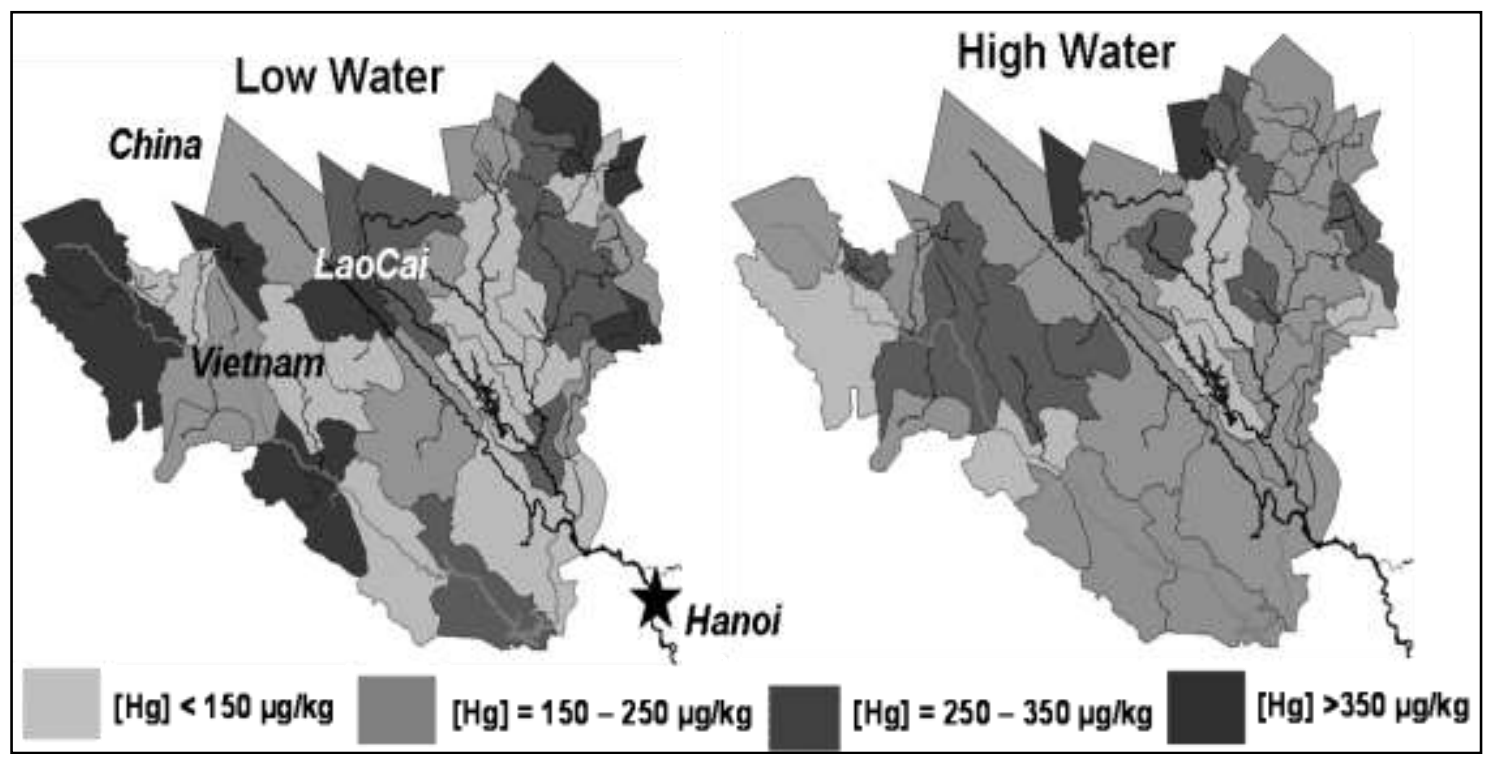

Figure 4. Spatial distribution of $\mathrm{Hg}$ concentrations in stream sediment from the Red River watershed at low and high water levels 
Vietnam Journal of Earth Sciences 36 (2014) 497-503

The Figure 4 shows that the high mercury anomalies are observed in the upstream of $\mathrm{Da}$ and Lo River (e.g. points 15, 16, 17, 18, LC, 37, 38 and 39) but also in the mid-catchment (e.g. 7, 11, 13, 14 and 32) in both high and low water levels. The source of this anomaly in the different subcatchments of the Red River watershed may be due to natural and/or anthropogenic. Based on an inventory of tailings, waste deposits etc. (from the mining map in Vietnam, 2008), we subdivide the sub-catchments into 2 groups: tailing group (visible presence of mining, smelting or urban wastes in the sub-catchment); and non-tailing group (no visible presence of mining, smelting or urban wastes in the sub-catchment). The result obtained is presented in Figure 3B. We observed that the $\mathrm{Hg}$ concentrations in the tailing group are clearly higher than those in non-tailing group, showing the strong impact of anthropogenic activities (mining and smelting) on river $\mathrm{Hg}$ concentrations (Figure 3B). However, to obtain more precise results, future researches need to measure $\mathrm{Hg}$ concentration in dissolved and particulate phases at the point sources and in the whole Red River watershed with high temporal and spatial resolutions.

\subsection{Estimation of potential toxic effects}

The sediment quality guidelines (SQG) were designed to assess contamination, protect aquatic life, support or maintain designated uses of freshwater, estuarine and marine environments, and to assist the quality of stream sediments (Balogh et al., 1998; Brigham et al., 2009; MacDonald et al., 2000; Maria et al., 1997). In this study, the $\mathrm{Hg}$ concentrations in stream sediments from the Red River watershed were compared to the consensus-based freshwater sediment quality guidelines (SQGs) proposed by MacDonald et al.(2008). The so-called Threshold Effect Concentration (TEC) represents concentrations of sediment-associated contaminants below which adverse effects on sediment-dwelling organisms are not expected to occur $(<20 \%)$. The Probable Effect Concentration (PEC) defines concentrations of sediment-associated contaminants above which adverse effects on sediment-dwelling organisms are likely to be observed (>90\%) (MacDonald et al.,2000).
For the mercury metal, the TEC and PEC values were $180 \mu \mathrm{g} / \mathrm{kg}$ and $486 \mu \mathrm{g} / \mathrm{kg}$, respectively. The Hg concentrations measured in the Red River were lower than the PEC level in the whole watershed (Figure 3A, Table 1). Thus, $\mathrm{Hg}$ concentrations (C) in the sediments from the Red River watershed were subdivided in 3 classes: i) $[\mathrm{Hg}]<\mathrm{TEC}$, ii) TEC $<[\mathrm{Hg}]<2 \mathrm{TEC}$, and iii) $2 \mathrm{TEC}<[\mathrm{Hg}]<\mathrm{PEC}$ and presented in table 1 .

Table 1. Mercury concentrations in comparison with the consensus-based freshwater sediment quality guidelines (SQGs) proposed by MacDonald et al.(2008)

\begin{tabular}{|c|c|c|c|c|c|c|c|c|c|c|c|c|c|}
\hline \multicolumn{6}{|c|}{ HighWater } & \multicolumn{8}{|c|}{ HighWater } \\
\hline Site & $\mathrm{C} 1$ & $\mathrm{C} 2 \mathrm{C} 3$ & Site & $\mathrm{C} 1$ & $\mathrm{C} 2 \mathrm{C} 3$ & Site & $\mathrm{C} 1$ & $\mathrm{C} 2$ & $\mathrm{C} 3$ & Site & $\mathrm{C} 1$ & $\mathrm{C} 2$ & $\mathrm{C} 3$ \\
\hline$\overline{\mathrm{LC}}$ & $x$ & & 21 & $\bar{x}$ & & $\overline{\mathrm{LC}}$ & & $x$ & & 21 & $x$ & & \\
\hline 2 & $\times$ & & 22 & $\times$ & & 2 & & $x$ & & 22 & $\times$ & & \\
\hline 3 & $\times$ & & 23 & $\times$ & & 3 & & & $x$ & 23 & $\times$ & & \\
\hline 4 & $\times$ & & 24 & $\times$ & & 4 & & & $\times$ & 24 & & $\times$ & \\
\hline PT & $\times$ & & 25 & & & PT & & & $x$ & 25 & & $\times$ & \\
\hline $\mathrm{Da}$ & $\times$ & & 26 & $\times$ & & $\mathrm{Da}$ & $\times$ & & & 26 & & $\times$ & \\
\hline 7 & $\times$ & & 27 & $x$ & & 7 & $\times$ & & & 27 & $\times$ & & \\
\hline 8 & $\times$ & & 28 & & $\times$ & 8 & & $\times$ & & 28 & & $\times$ & \\
\hline 9 & $\times$ & & 29 & & $x$ & 9 & $\times$ & & & 29 & & $\times$ & \\
\hline 10 & $\times$ & & 30 & & $x$ & 10 & $\times$ & & & 30 & & & $\times$ \\
\hline 11 & $\times$ & & 31 & $\times$ & & 11 & $x$ & & & 31 & $x$ & & \\
\hline 12 & $\times$ & & 32 & $\times$ & & 12 & $\times$ & & & 32 & & $\times$ & \\
\hline 13 & $\times$ & & 33 & $\times$ & & 13 & $x$ & & & 33 & $\times$ & & \\
\hline 14 & $\times$ & & 34 & $\times$ & & 14 & & $x$ & & 34 & $x$ & & \\
\hline 15 & $\times$ & & 35 & $\times$ & & 15 & $x$ & & & 35 & $x$ & & \\
\hline 16 & $\times$ & & 36 & & $\times$ & 16 & & & $\times$ & 36 & $\times$ & & \\
\hline 17 & & $\times$ & 37 & & $\times$ & 17 & & $\times$ & & 37 & & $\times$ & \\
\hline 18 & $\times$ & & 38 & $\times$ & & 18 & $\times$ & & & 38 & & $\times$ & \\
\hline Lo & & $x$ & 39 & & $\times$ & Lo & $\times$ & & & 39 & $\times$ & & \\
\hline 20 & $\times$ & & ST & $\times$ & & 20 & $x$ & & & ST & & $x$ & \\
\hline
\end{tabular}

C1: class $1([\mathrm{Hg}]<\mathrm{TEC}), \mathrm{C} 2$ : class 2 (TEC $<[\mathrm{Hg}]<2 \mathrm{TEC})$ and C3: class $3(2 \mathrm{TEC}<[\mathrm{Hg}]<\mathrm{PEC})$

The Table 1 showed that during high water condition, in almost all the Red River watershed, the mercury concentrations measured were lower than the TEC level. In contract, during low water condition, $50 \%$ values of $\mathrm{Hg}$ concentration measured exceeded the TEC level and $12.5 \%$ values varied between 2 TEC and the PEC values, suggesting that the sediment quality for important areas of the Red River watershed during low water level is rather poor and the potential effects of sediment-associated contaminants in aquatic life of the Red River are relatively high ( 20-90\%). These observations are very important for 


\section{Dang Thi Ha et al./Vietnam Journal of Earth Sciences 36 (2014)}

assessing the different sediment management objectives in the Red River watershed.

\section{Concluding remarks}

Based on mercury concentrations measured in stream sediments from 40 sampling sites in the Red River watershed, the spatial and seasonal variations of $\mathrm{Hg}$ concentrations were determined. The Hg concentrations varied between 71 and 475 $\mu \mathrm{g} / \mathrm{kg}$ in low water condition and between 66 and $241 \mu \mathrm{g} / \mathrm{kg}$ in high water condition, showing a strong spatial-seasonal variation of $\mathrm{Hg}$ concentrations. The high anomaly of $\mathrm{Hg}$ concentrations may be due to anthropogenic sources (mining, smelting...) located in the Red River watershed. Finally, the estimation of potential toxic effects based on the sediment quality guidelines suggested serious effects of sediment-associated contaminants in aquatic environment of the Red River, especially during low water condition.

\section{Acknowledgement}

The studies received the supports from University of Bordeaux 1 (France) and funded by the INSU-ST River Song program.

\section{References}

Adrienne, R.F., Peter, V.H., Brian, C.H., 2008: Spatial and seasonal patterns of mercury concentrations in fish from the St. Lawrence River at Cornwall, Ontario: Implications for monitoring. Journal of Great Lakes Research 34, 72-85.

Balogh, S., Meyer M., Kentjohnson, D., 1998: Transport of mercury in three contrasting river basins. Environ. Sci. Technol.32, 456-462.

Berg, M., Stengel, C., Phạm, T.K.T., Pham, H.V., Sampton, M.L., Leng, M., 2007: Magnitude of arsenic pollution in the Mékong and Red River Deltas-Cambodia and Vietnam, Science of the Total Environment 327, 413-425.

Brigham, M., Wentz, D., Aiken, G., Krabbenhoft, A., 2009: Mercury cycling in stream ecosystems.1. Water column chemistry and transport. Environ. Sci. Technol. 43, 27202725 .

Coynel, A., Blanc, G., Marache, A., Schäfer, J., Dabrin, A.,
Maneux, E., Bossy, C., Masson, M., Lavaux, J., 2009: Assessment of metal contamination in a small mining- and smelting-affected watershed: high resolution monitoring coupled with spatial analysis by GIS, J Environ Monit.11, 962-976.

Dang, T.H., Coynel, A., Grosbois, C., Blanc, G., Orange, D., Etcheber, H., Le, L.A., 2011: Distribution, source and flux of arsenic in a typical humid tropics river originating from the Himalaya Mountains: the Red River watershed (China/Vietnam). Proceeding of 23eme RST conference, Bordeaux, France.

Dang, T.H., Coynel, A., Orange, D., Blanc, G., Etcheber, H., Le, L.A., 2010: Long-term monitoring (1960-2008) of the river-sediment transport in the Red River Watershed (Vietnam): temporal variability and dam-reservoir impact. Science of the Total Environment 408, 4654-4664.

Guangle, Q., Xinbin, F., Shaofeng, W., Tangfu, X., 2006: Mercury contaminations from historic mining to water, soil and vegetation in Lanmuchang, Guizhou, southwestern China. Science of the Total Environment 368, 56-68.

Ho, T.L.T., Cao, T.S., Tran, T.L., Kurosawa, K., Egashira, K., 2010: Assessment of surface and groundwater quality in pig-raising villages of Hai Duong province in Vietnam. Journal of the Faculty of Agriculture, Kyushu University $55,123-130$.

Le, T.P.Q., Garnier, J., Gilles, B., Sylvain, T., Chau, V.M., 2007: The changing flow regime and sediment load of the Red River, Viet Nam. Journal of Hydrology 334, 199-214.

MacDonald, D.D., Ingersoll, C.G., Berger, T. A., 2000: Development and Evaluation of Consensus-Based Sediment Quality Guidelines for Freshwater Ecosystems. Arch. Environ. Contam.Toxicol.39, 20-31.

MacFarlane, M., 2004: Mercury concentrations in water and sediment in Resurrection Creek, Alaska.Final Report, 27p.

Maria, H.D.P., Milton, L.L.F., Elba, C.T., 1997: Heavy metals in stream sediments from copper and gold mining areas in southern Brazil. Journal of Geochemical Exploration 58, 133-143.

Mlayah, A., Ferreira da Silva, E., Rocha, F., Ben Hamza, Ch., Charef, A., Noronha, F., 2009: The OuedMellègue: Mining activity, stream sediments and dispersion of base metals in natural environments, North-western Tunisia. Journal of Geochemical Exploration 102, 27-36. 


\section{Vietnam Journal of Earth Sciences 36 (2014) 497-503}

Nguyen, M.P., Kang, Y., Sakurai, K., Iwasaki, K., Chu, N.K., Nguyen, V.N., Le, T.S., 2010: Levels and Chemical Forms of Heavy Metals in Soils from Red River Delta, Vietnam. Water, Air, and Soil Pollution 207, 319-332.

Schäfer, J., Blanc, G., Audry, S., Cossa, D., Bossy, C., 2006: Mercury in the Lot-Garonne River system (France): Sources, fluxes and anthropogenic component. Applied Geochemistry 21, 515-527.

Spadini, L., Charlet, L., 2003: Distribution of anthropogenic mercury in French Guyana river sediments downstream from gold mining sites. Journal of Physical IV France 107, 1263-1266.

Subramanian, V., Madhavan, N., Rajinder, S., Lundin, L.C., 2003: Nature of distribution of mercury in the sediments of the River Yamuna (tributary of the Ganges), India. J. Environ. Monit.5, 427-.

Viers, J., Dupréa, B., Gaillardet, J., 2008: Chemical composition of suspended sediments in World Rivers: New insights from a new database. doi:10.1016/j.scitotenv.2008.09.053. 